\title{
Carbon Sequestration Potential from Large-Scale Reforestation and Sugarcane Expansion on Abandoned Agricultural Lands in Brazil
}

\author{
Iván García Kerdan ${ }^{1}$ (D) - Sara Giarola ${ }^{2}$ - Francisca Jalil-Vega ${ }^{1} \cdot$ Adam Hawkes $^{1}$
}

Received: 29 April 2019 / Revised: 6 August 2019 / Accepted: 13 August 2019 / Published online: 29 August 2019

(C) The Author(s) 2019

\begin{abstract}
Since 1850 , over $145 \pm 16 \operatorname{PgC}(\mu \pm 1 \sigma)$ has been emitted worldwide due to land-use change and deforestation. Besides industrial carbon capture and storage (CCS), storing carbon in forestry products and in regenerated forest has been recognized as a cost-effective carbon sequestration option, with an estimated worldwide sink potential of about $50-100 \mathrm{PgC}$ (15-36 PgC from tropical forest alone). This paper proposes the expansion of a Brazilian integrated assessment model (MUSE-Brazil) by integrating a non-spatial biomass-growth model. The aim is to account for carbon sequestration potential from either reforestation or sugarcane expansion in abandoned agricultural lands. Modelling outputs suggest that Brazil has the potential to liberate up to 32.3 Mha of agricultural land by 2035, reaching 68.4 Mha by mid-century. If a sugarcane expansion policy is promoted, by 2050 , the largest sequestration rates would come from above and below ground biomass pools; gradually releasing to the atmosphere around $1.6 \mathrm{PgC}$ or $1.2 \%$ of the current Brazilian land carbon stock due to lower SOC carbon pools when turning agricultural lands into sugarcane crops. On the other hand, a reforestation-only scenario projects that by 2035 the baseline year carbon stock could be recovered and by 2050 the country's carbon stock would have been increased by $3.2 \mathrm{PgC}$, reaching annual net sequestration rates of $0.1 \mathrm{PgC} \mathrm{y}^{-1}$, mainly supported by natural vegetation regeneration in the Cerrado biome.
\end{abstract}

Keywords Land use $\cdot$ Energy systems model $\cdot$ Sugarcane $\cdot$ Reforestation $\cdot$ Carbon sequestration $\cdot$ Brazil

\section{Introduction}

At the COP21 meeting, 195 nations have consented to restrict climate change to well underneath $2{ }^{\circ} \mathrm{C}$ (UN 2015). The agriculture, forestry and land use (AFOLU) sector is responsible of around $24 \%$ of global anthropogenic emissions (IPCC 2014). The sector is essential in accomplishing reduction targets by reducing $\mathrm{CH}_{4}$ and $\mathrm{N}_{2} \mathrm{O}$ emissions from farming and decreasing $\mathrm{CO}_{2}$ emissions from deforestation (De Oliveira Silva et al. 2018; Hasegawa and Matsuoka 2010; Scherer et al. 2018).

Iván García Kerdan

i.garcia-kerdan@imperial.ac.uk

1 Department of Chemical Engineering, Imperial College London, London, UK

2 Department of Earth Science \& Engineering, Imperial College London, London, UK
Research with respect to diverse carbon sequestration processes in the AFOLU sector and in negative emissions technologies to offset the insufficient reduction in carbon emissions by the energy sector has been growing in the last decade (Minx et al. 2017). Bioenergy crops, either for biofuels production or for electricity generation, have the capacity of decreasing emissions by substituting fossil fuels. Recent research has calculated that the maximum global bioenergy supply potential stands just below $1300 \mathrm{EJ} \mathrm{y}^{-1}$ (Haberl et al. 2010; Raphael Slade et al. 2011; Smeets et al. 2007); however, if technical and economic constraints are considered, this value decreases to around 130-400 $\mathrm{EJ} \mathrm{y}^{-1}$ (Deng et al. 2015). Nijsen et al. (2012) calculated a potential at around 150-190 $\mathrm{EJ} \mathrm{y}^{-1}$, mainly coming from woody crops and grass from marginal lands.

Still, several uncertainties exists, especially those related to the full bioenergy production life cycle emissions (Plevin et al. 2010). Regardless, biomass production is seen as an essential energy source to achieve climate change targets, as most mitigation pathways consider the wide implementation of 
biomass combined with carbon capture and storage processes (BECCS) (Azar et al. 2010). BECCS has been found to possess the best abatement potential within the power and industrial sectors with three main CCS technologies: i) pre-combustion, ii) post-combustion and iii) oxy-combustion, and with a variety of separation technologies (absorption, adsorption, membrane, etc.). However, the ecosystems and social implications of large-scale bioenergy production as well as the high capital costs of CCS technologies still need to be carefully assessed (Muratori et al. 2016). On the other hand, land management techniques such as biochar, soil carbon sequestration (SCS) and reforestation/afforestation could support carbon mitigation actions at low-cost (Minx et al. 2017). Recent studies have shown carbon benefits of restoring abandoned lands to their original state (Evans et al. 2015; Silver et al. 2000); however, similar to BECCS, there is high uncertainty in its large-scale implementation.

For Smith et al. (2013) and Yue et al. (2017), reducing meat-based diets could have larger carbon abatement potentials, mainly arising from a reduction in land and agrochemicals demand. Nevertheless, future food demand projections (FAO 2017) and lack of sustainable bioenergy policies, would put severe pressure on the land system. In some countries, the degradation of natural forest for agricultural production still remains, causing a severe environmental damage. Optimal land use management and new technologies would be necessary to increase production, minimizing the demand for new lands, allowing abandoned agricultural lands to recover their natural vegetation (FAO 2017; IPCC 2014).

Silver et al. (2000) studied the carbon sequestration potential by reforestation of tropical lands. The authors identified the importance of previous agricultural land use on carbon (C) sequestration rates of biomass and soils. For instance, forests growing in previous cropland have the capacity to accumulate faster quantities of biomass due to high relative fertility, while soil organic carbon accumulates faster in former pasture lands. Krause et al. (2017) studied the carbon removal through growth of bioenergy crops via CCS and afforestation, aiming to find an optimal share to assess trade-offs of different ecosystem parameters such as surface albedo, nitrogen loss, and carbon storage. Nonetheless, reforestation strategies also have their disadvantages. One of the main limitations of forest management is the rate of decomposition that eventually releases $\mathrm{CO}_{2}$. Some authors have suggested that more appropriate forest management techniques considering sustainable wood harvest, production of wood materials and wood storage combined with BECCS could provide a more sustainable solution. Ni et al. (2016) suggested that active harvesting strategies at a constant rate without affecting the new forest albedo are necessary and could achieve greater GHG abatement potential. The main advantage of this approach compared to industrial CCS is its lower capital and operational cost $(\$ 25-50$ against $\$ 100-\$ 160$ tonCO $\mathrm{CO}_{2}^{-1}$ ).

\subsection{AFOLU GHG Abatement Models}

Energy and 'agricultural \& land use' models are set to play a significant role in supporting policy and decision makers in climate change mitigation policies. This is particularly relevant for this sector, which would appear having a crucial role in mitigation potential, but is at the same time characterized by large uncertainties.

Kraxner et al. (2003) developed MOSES, a forest (single tree) growth model capable to analyse forestbiomass energy systems dynamics in temperate regions. The authors demonstrated that forestry management and bioenergy growth in temperate forests could lead to the stabilization and absorption of $\mathrm{CO}_{2}$ emissions from the atmosphere, focusing on the advantages of BECCS as a measure to achieve negative emissions. The authors showed that reforestation and BECCS have the global potential to permanently remove 2.5 ton $\mathrm{C} \mathrm{yr}{ }^{-1} \mathrm{ha}^{-1}$. Contrarily, Evans et al. (2015) compared the mitigation potentials of a wide range of scenarios regarding reforestation and biofuel production on marginal or abandoned land over a 30 year period. To calculate $\mathrm{C}$ sequestration potential of recovered forest, a statistical analysis of temperate and tropical forests was used. The authors showed that reforestation has a larger abatement potential compared to low yielding biofuel production. Compared to gasoline production, switch grass ethanol has the largest offset emission potential (126\% reduction), followed by sugarcane ethanol (96\%), Miscanthus ethanol (95\%), and corn ethanol (70\%). Compared to diesel production, oil palm biodiesel has a reduction potential of about $65 \%$.

Ethanol production combined with CCS has the capability to deliver negative emissions to the energy system and could become economically competitive in the near future, as to date, the main barrier for its largescale implementation is the large cost of capturing and transporting $\mathrm{CO}_{2}$. Moreira et al. (2016) presented the analysis of BECCS applied to an ethanol fermentation process (considering also the production of bioelectricity). The authors found that the process would increase ethanol price by around $3.5 \%$, with potential of governmental subsidies aiming at reducing final consumer price. Recently, Freitas et al. (2019) presented a techno-economic and thermodynamic analysis of a sugarcane-based ethanol bio-refinery demonstrating its potential to generate negative emissions. In this study, 
the economic viability of integrating $\mathrm{CCS}$ into the ethanol production process has been increased by using the captured $\mathrm{CO}_{2}$ for enhanced oil recovery (EOR).

Albanito et al. (2016) assessed the potential implication of land use change from current cropland to either bioenergy or forest. The study developed a spatially explicit framework using several models: the spatial production allocation model (SPAM), LPJmLDGVM, and the IPCC Tier 1 method. As a case study, the authors compared $\mathrm{C} 4$ grass (miscanthus and switch-grass), wood energy crops and reforestation. Globally, the authors estimated that around 420 Mha of the current 1100 Mha of cropland, if converted to either forest or bioenergy will result in a net carbon loss. On the other hand, planting either miscanthus and/or switch-grass represents the highest abatement potential in 485 Mha, with a carbon uptake of $58 \mathrm{PgC}$. Most of these lands will be terrain with slopes above 20\%. Wood-based energy crops, such as Eucalyptus, poplar and willow, are only the best option in 26.3 Mha of current cropland with an abatement potential of $0.9 \mathrm{Pg}$. Finally, reforestation provides the best option on 185 Mha with an abatement potential of $5.8 \mathrm{PgC}$ from biomass and 2.7 $\mathrm{PgC}$ from soil carbon.

Dwivedi et al. (2016) developed a carbon forest model aiming at determining the efficiency of bioenergy and carbon markets in GHG abatement of reforested lands. Two scenarios were explored: a carbon market that could lead to an increase in forest rotation rates, and a wood-based bioenergy market that could lead to short rotation ages by selling small-diameter wood products. Findings suggest that increasing rotation times doesn't necessarily increase carbon stocks compared to normal rotations. In some regions, such as the UK, transforming all wood products into wood pellets for electricity generation leads to carbon saving offsetting emissions from fossil-fuel based plants. However, appropriate policies should be put in place to maximize the carbon saving potential of forests without any impact to the ecosystem.

To the best of the authors' knowledge, there is a lack integrated assessment models (IAMs) that combine appropriate agricultural energy technology diffusion (mechanization) with robust land use dynamics and the implications of energy and ecosystem measures in GHG abatement. The aim of this study is to develop a framework capable of modelling mechanization adoption and land intensification/extensification, as well as modelling reforestation and sugarcane expansion as a carbon negative measure and its wider implications in the energy and land use systems. To achieve this, MUSE-Brazil, a multi-sectoral/multi-regional energy system model has been expanded to account for land use and terrestrial emissions. The study framework is proposed in two stages. First, the model is used to simulate future energy demand and agricultural mechanization diffusion and its implications in land use and land clearing under a reference scenario. Secondly, the model is applied to study the carbon capture and sequestration potential through either i) sugarcane expansion or ii) reforestation, in abandoned agricultural lands with a focus on understanding their impacts on terrestrial emissions and the energy system.

The paper is organized as follows. First, an overview of the methodology and the modelling framework is presented. Secondly, the case study of Brazil's land, reforestation and sugarcane context is discussed. Then, the paper shows the obtained results, followed by discussions and conclusions.

\section{Methodology}

MUSE-Brazil, is a technology-rich bottom-up regional model that simulates energy, land use demand and carbon emissions in the medium and long-term (up to 2100) (García Kerdan et al. 2019) (Fig. 1). The model follows a simulation approach aiming to model real-world investors' decision making in each sector, where different methods and metrics can be implemented (e.g. ranging from merit-order simulation methods to agent-based modelling). Particularly, the model's agricultural and land use module (Ag\&LU) aims to provide the required technological share and related energy consumption and emissions by meeting four general agricultural services: a) agricultural crops, b) animal-based products, c) wood products and d) energy crops. At each iteration, the Ag\&LU model will dynamically exchange a set of parameters (fuel, emissions, etc.) with the Market Clearing Algorithm (MCA). The MCA connects all the different energy modules and is responsible for the data flow between sectors. Generally, the MCA will iterates between modules until each energy commodity's price and quantity converge (Crow et al. 2018). The model's simulation framework is shown in Fig. 1.

In this paper, MUSE-Brazil's Ag\&LU module has been expanded to simulate land use requirements and related emissions. Inherited in the model is a process of simulating mechanization uptake at each agricultural commodity while also accounting for growing demands due to increase income and total population. The new additions make the model capable of relating technological or mechanization diffusion while predicting its impact on land use and land use clearing. Additionally, it can simulate deforestation and reforestation rates under different policies, providing a deeper understanding on the impacts of land use on carbon emissions. The model calculates available land liberated from previous 
Fig. 1 MUSE-Brazil modelling framework (top) and the Ag\&LU module integration into MUSE (Data flow with the MCA) (bottom)

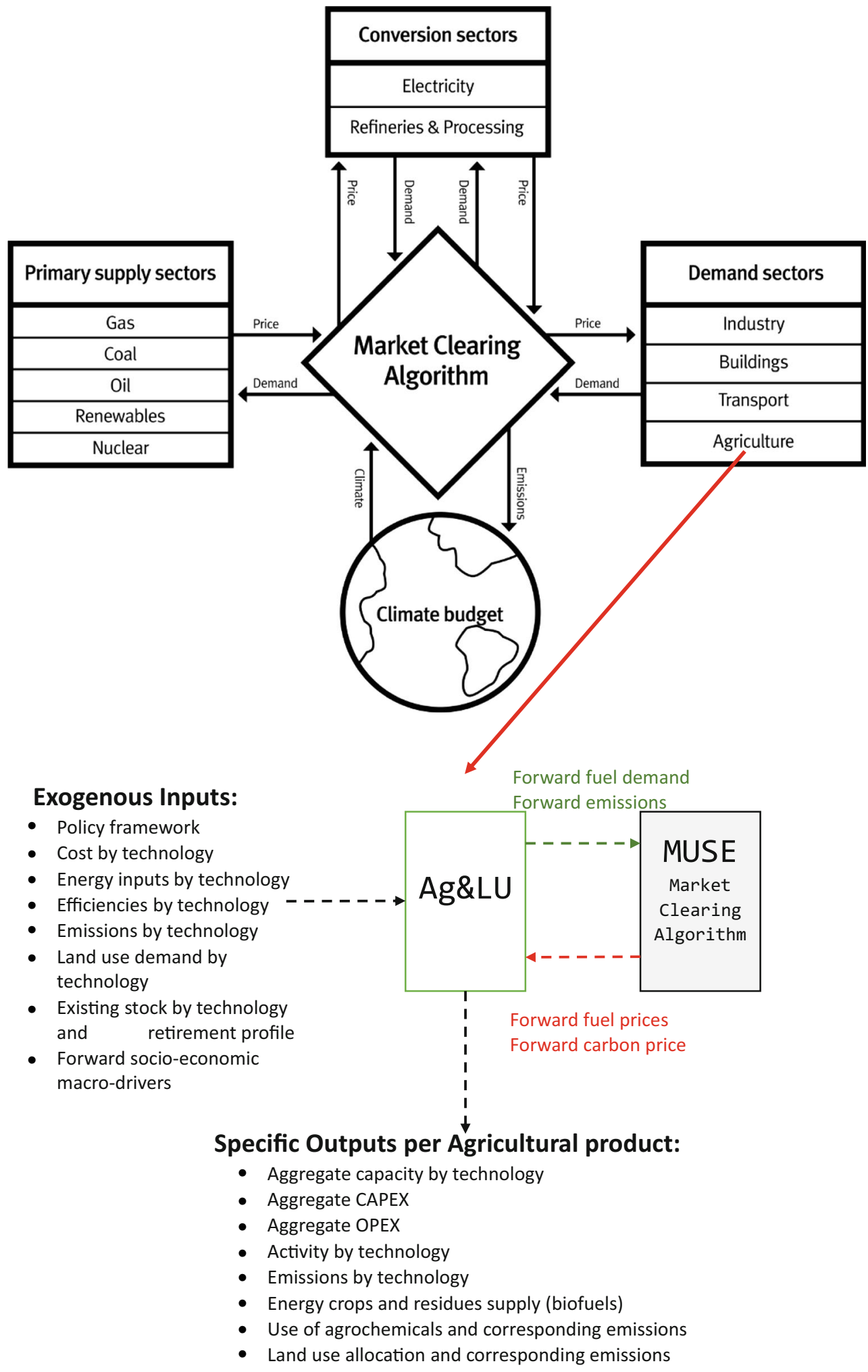

agricultural land (cropland, pasture land, bioenergy land) and depending on the demand of agricultural commodities, it simulates land competition based on project's profitability. It can be constrained to limit land use expansion depending on explicit regional characteristics or environmental policies.

\subsection{Land Use and Land Use Change Emissions}

In Ag\&LU-SM, eight different land types are modelled (Table 1): 
To account for emissions deriving from the management of land, the model integrates the IPCC Tier 1 calculation methodology (IPCC 2006). This non-spatial method provides net emissions changes for diverse land use categories over a predefined period considering the following carbon pools: above and below ground biomass, soil organic carbon (SOC) and dead organic matter (DOM). To calculate carbon stock changes at two points of time, the stock-difference method has been used:

$\Delta C_{l}=\frac{\left(C_{l, t 2}-C_{l, t 1}\right)}{\left(t_{2}-t_{1}\right)}$

where $\Delta C_{l}$ is the change between periods in carbon stocks in the pool $l, C_{l, t 1}$ is the carbon stock at time 1 and $C_{l, t 2}$ is the carbon stock at time 2 . To account for changes in the carbon stock for each land type, eq. 2 is used:

$\Delta C_{L U_{i}}=\Delta C_{A B}+\Delta C_{B B}+\Delta C_{D O M}+\Delta C_{S O C}$

where $\Delta C_{L U_{i}}$ is carbon change for land use type $I$ in the four carbon pools (above ground biomass, below ground biomass, dead organic matter and soil organic carbon). Finally, eq. 3 is used to account for the entire carbon stock changes per land-use type:

$\Delta C_{t o t}=\sum_{i} \Delta C_{L U_{i}}$

where $\Delta C_{\text {tot }}$ is total carbon stock change. Land changes between types are also considered, as carbon dynamics vary depending on the former and latter land use type (e.g. cropland to forest, pasture to forest). These values, obtained from Guo and Gifford (2002) can be found in the Appendix (Table 8). The method has been proposed to estimate with better accuracy carbon sequestration/release from either forest recovery or new agricultural crops.

\subsection{Case Study}

In this paper, Brazil is used as a case study. The original model (MUSE-Brazil) has been separated into five major geo-political regions (North, North-East, Centre-West, South-East, and South) to account for regional socio-economic differences, projecting different pathways depending on specific scenarios. For this study, a further ecosystem layer has been characterized. For this, IBGE (IBGE 2018) and FAOSTAT (FAO 2017) data have been used to characterize land use by biome (Fig. 2). Forest land by biome (Fig. 2) has been gathered from the MME (MME 2018), while for regional sugarcane land use UNICA (UNICA 2018) data has been collected.

As biomes can be found in different regions, this has to be characterized in MUSE, as the model's main geographical characterization is based on Brazil's geopolitical regions. Thus, C stocks per unit area have been considered to calculate total regional $\mathrm{C}$ stocks. Table 2 shows the amount of land in each region while Table 3 presents calibrated total land demands by type and by region.

To understand the regional land use differences, Fig. 3 illustrates the share per land type in each region. Large amounts of forest land in most of the regions are noticeable in this figure, particularly in the North and North-East. Cropland and pasture land are more predominant in the Centre-West and South-East, while silviculture is more important in the South-East and South regions. Additionally, the South-East region has the largest amount of sugarcane plantations compared to the rest of the country.

\subsection{Carbon Stock Characterization}

The forest ecosystems in different biomes play an important role in the Brazilian carbon cycle. Different sources have been used to characterize the C stocks for each biome (IPCC 2006; MMA 2017). Table 4 illustrates the mean values for carbon stocks for each land type used in this research.

The total Brazilian carbon stock has been calculated at 135.9 PgC, with the North region representing 70.7\%, mainly due to the 310 Mha of the Amazon forest. Considering Turner et al. (1998) study as basis, which calculated the total Brazilian carbon stock at $152.6 \mathrm{PgC}$ in 1990 , this means that approximately $11 \%$ of the carbon pool have been lost between 1990 and 2010. Nevertheless, several uncertainties exist when measuring carbon stocks in different pools. For instance, studies have calculated that only the Amazon, the carbon content
Table 1 Land types simulated in Ag\&LU-SM

\begin{tabular}{ll}
\hline Type & Description \\
\hline 1. Cropland & Land for diverse crop cultivation \\
2. Pasture land & Land for grazing livestock \\
3. Forestry products & Land for silviculture (wood production) \\
4. Energy crops & Land for dedicated energy crops \\
5. Natural forest & Land for primary and regenerated forest \\
6. Non-arable land & Land unsuitable for farming (e.g. desert, ice, tundra, rock) \\
7. Urban/Infrastructure & Land dedicated to human settlements and other non-natural infrastructure \\
8. Available & Land cleared due to agricultural intensification \\
\hline
\end{tabular}




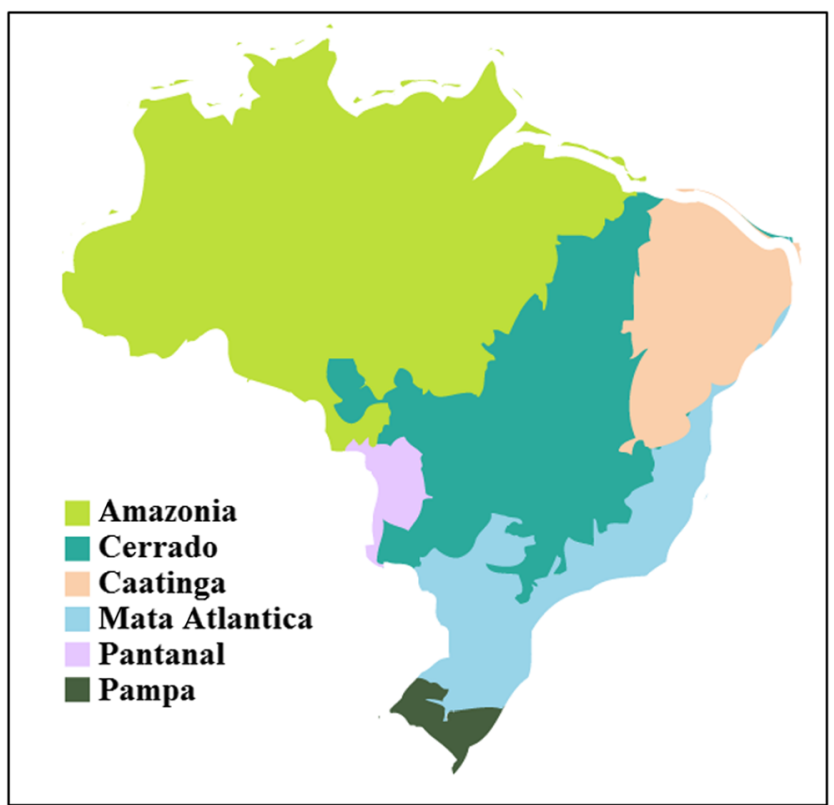

Fig. 2 Brazil's biomes. Source: EMBRAPA (2019)

could lie between 138 and $348 \mathrm{PgC}$ (Fearnside 2018; Nobre et al. 2016; Quijas et al. 2019). Main differences arise due to application of different measurements methods and distinct depths in the soil organic carbon (SOC) pool.

\subsection{Scenarios: Sugarcane Expansion or Reforestation}

First, a carbon constrained $\left(2{ }^{\circ} \mathrm{C}\right)$ reference scenario is simulated using 2010 as base year with a time-horizon to 2050, to obtain regional liberated land (if any) at each time step (every 5 years). For the reference scenario, a forecast for agricultural commodities has been done using IIASA SSP2 data (Fricko et al. 2017). The SSP2 narrative describes a middle-of-the-road development in mitigation and adaptation. For food and agricultural products demand, which have large implications in land use, regression results suggest that the national food intake will grow from a base-year value of $739 \mathrm{PJ} \mathrm{y}^{-1}$ and $232 \mathrm{PJ} \mathrm{y}^{-1}$ of crop and animal-based food respectively to about $868 \mathrm{PJ} \mathrm{y}^{-1}$ and $300 \mathrm{PJ}$ $\mathrm{y}^{-1}$ by 2050 (17.3\% increase in food crops and $29.3 \%$ in meat products). The regions with the highest demand growth rates are the Centre-West, with a demand increase of $36.5 \%$ for food crops and $48.2 \%$ for meat, and the North with $34.6 \%$ and $45.8 \%$ for crops and meat respectively. Total food demand increase by regions can be seen in the Appendix (Table 9).

To calculate land demand, the production increase levels for agricultural crops and meat production has been taken from assumptions made by the Brazilian government (EPE 2016). In general, most of Brazil studies assume that crop yields will grow on average $1.5 \%$ per year while meat production will intensify linearly from an average base-year value of 1.0 to 1.7 heads per hectare by 2050. In this study these values have been used as constraints, and the model's technological choice at each period determines the simulated yield growths. Additionally, it has been considered that urban land will not change over time.

Following, the model is applied under two different policy scenarios considering the land and land systems. One scenario explores the expansion of sugarcane on the cleared agricultural land (sugarcane expansion scenario), while the second scenario assumes an exclusive reforestation process (reforestation scenario).

For sugarcane expansion, endogenous regional yield improvement is considered through intensification of production practices. Additionally, the model considers a minimum ethanol production of 50 billion litres by 2030 , based on the current targets from the National Biofuels Policy (RenovaBio) programme (PLANALTO 2017). For the model calibration, regional average yields have been used (UNICA 2018). For future yields projections, it has been assumed that most of the regions will reach by 2050 a maximum value of 75 th percentile. This acts as a constraint in the model. Figure 4 shows the current sugarcane yields distribution in ton $\mathrm{ha}^{-1}$ for the five analysed regions.

Table 5 presents the baseline values used in the calibration as well as the expected maximum yields by the end of the simulation period. The assumed projected yields will be increased within historical projection rates, keeping modelling assumptions realistic.

Although some distributions are similar among regions, land use potential for sugarcane expansion vary greatly due

Table 2 Estimated area of natural forest in Brazilian biomes. Adapted from MME (2018)

\begin{tabular}{|c|c|c|c|c|c|c|}
\hline Biome/Region & North & $\begin{array}{l}\text { North- } \\
\text { East }\end{array}$ & Centre-West (Mha) & $\begin{array}{l}\text { South- } \\
\text { East }\end{array}$ & South & Total \\
\hline Amazonia & 305.4 & 2.7 & 33.6 & - & - & 341.6 \\
\hline Caatinga & - & 41.4 & - & - & - & 41.4 \\
\hline Cerrado & 4.6 & 18.0 & 13.5 & 4.1 & 0.0 & 40.3 \\
\hline Mata Atlántica & - & 3.4 & 1.3 & 11.1 & 8.3 & 24.1 \\
\hline Pampa & - & - & - & - & 2.8 & 2.8 \\
\hline Pantanal & - & - & 8.9 & - & - & 8.9 \\
\hline Total & 310.0 & 65.4 & 57.3 & 15.2 & 11.2 & 459.1 \\
\hline
\end{tabular}


Table 3 Base-year (2010) land use characterization for the five Brazilian regions

\begin{tabular}{|c|c|c|c|c|c|c|}
\hline Land type & North & $\begin{array}{l}\text { North- } \\
\text { East }\end{array}$ & Centre-West (Mha) & $\begin{array}{l}\text { South- } \\
\text { East }\end{array}$ & South & Total \\
\hline Cropland & 3.7 & 9.6 & 25.5 & 20.8 & 8.2 & 67.8 \\
\hline Bioenergy $^{\Delta}$ & 0.0 & 1.1 & 1.9 & 6.0 & 0.7 & 9.7 \\
\hline Forest & 310.0 & 65.4 & 57.3 & 15.2 & 11.2 & 459.1 \\
\hline Other natural vegetation & 20.3 & 45.3 & 0.4 & 1.1 & 12.2 & 79.3 \\
\hline Silviculture & 0.3 & 0.8 & 0.7 & 2.9 & 1.9 & 6.7 \\
\hline Non-arable & 6.7 & 5.1 & 4.8 & 2.5 & 2.1 & 21.2 \\
\hline Pasture & 45.2 & 27.2 & 69.4 & 36.9 & 19.1.4 & 197.8 \\
\hline Urban & 1.3 & 3.8 & 0.9 & 5.7 & 1.8 & 13.5 \\
\hline
\end{tabular}

${ }^{\Delta}$ Only sugarcane is considered

to regional biophysical characteristics. New sugarcane expansion has been constrained using Brazil's agro-ecological mapping (MAPA 2009). According to the report, the maximum suitable areas for new sugarcane plantations are located in the Centre-west (30.3 Mha), followed by the South-East (22.7 Mha), South (5.7 Mha), North-East (5.2 Mha) and North (1.1 Mha). These constraints have been considered in the modelling exercise. On the other hand, reforestation is assumed as long as cleared land is available, considering 30year growing maturity rates affecting the carbon uptake.

\section{Results}

\subsection{Reference Case}

In the reference scenario (Fig. 5), cleared land (available) is mainly represented by former crop and pasture lands. It is expected that demand for agricultural land (crops, pasture, bioenergy and silviculture) would peak by 2020 reaching 292 Mha (an increase of $3.5 \%$ ). Then, due to agricultural

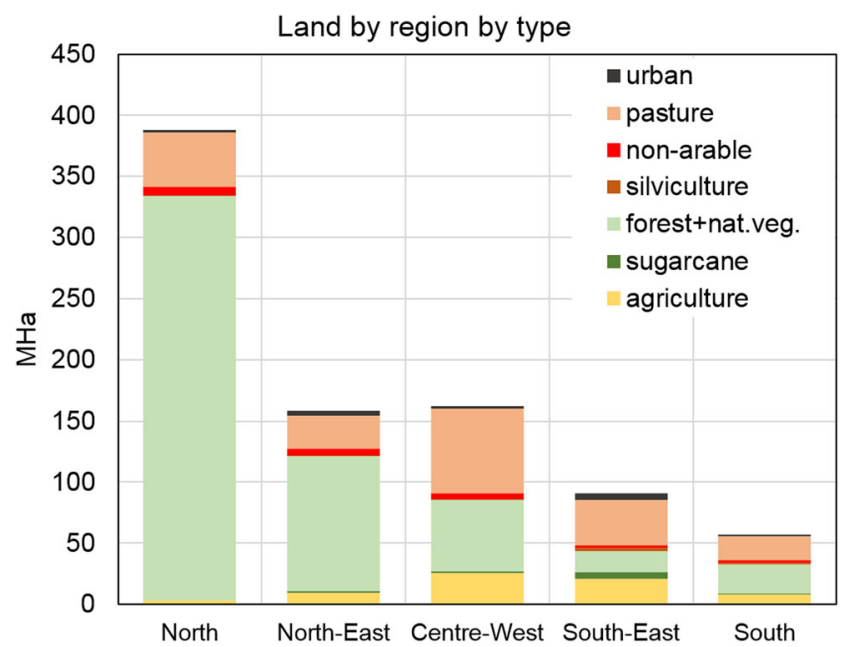

Fig. 3 Land use demand and land use share by region intensification, especially for pasture, the sector is expected to liberate land at a rate of $6.0 \%$ annually, occupying $230 \mathrm{Mha}$ by 2050 , thus liberating 68 Mha of land or $8.0 \%$ of the total Brazilian territory. Regionally, the Centre-West region, with typical large pasture lands, provides the largest amount of cleared land with 23 Mha, followed by the North (14 Mha) and South-East (13 Mha). Natural forest land, originally comprised by 459 Mha in the base year, would be reduced to 443 Mha by 2050. Most of the reduction arises during the first 15 years (2010-2025), with the Centre-West responsible of $85 \%$ (13 Mha) of the total deforestation. The detail of the land demand by region can be seen in the Appendix (Fig. 12).

Figure 6 shows the carbon stock dynamics in each region. As the simulation progresses, carbon losses can be appreciated at a rate of $0.1 \%$ annually, reducing the national carbon stock from 135.9 $\mathrm{PgC}$ in 2010 to $129.9 \mathrm{PgC}$ by 2050. Main carbon emissions arise from agricultural land's SOC pools and loss in above-ground biomass ( $\mathrm{AB}$ ) from deforestation. Regionally, the Centre-West provides the largest losses with 3.5 PgC, followed by the South-East region with $0.7 \mathrm{PgC}$. By land type, the maximum contributor in $\mathrm{C}$ loss is deforestation with 3.4 $\mathrm{PgC}$, followed by pasture lands with $2.3 \mathrm{PgC}$. On the other hand, thanks to an increase in sugarcane production from 620 to $1135 \mathrm{Mt}$ and an increase of $38 \%$ of land demand, sugarcane land is able to sequester $0.24 \mathrm{PgC}$ by 2050 , offsetting some of its $\mathrm{C}$ losses from deforestation. This deforestation occurs when cleared land that becomes available for sugarcane production is not able to entirely cover the sugarcane land expansion in a specific period.

Figure 7 shows the carbon stock changes. All regions contribute to carbon losses at each period to some extent. By land type, the expansion of pasture in the first decade over recent liberated land from cropland and low-carbon forested areas, has contributed to sequester carbon mainly in the SOC pools. In 2030, the model presents a sudden negative $\mathrm{C}$ stock change, mainly located in the Centre-West region. The reason is the large quantities of pasture land liberation in the region due to a more intense agricultural mechanization occurring during that 


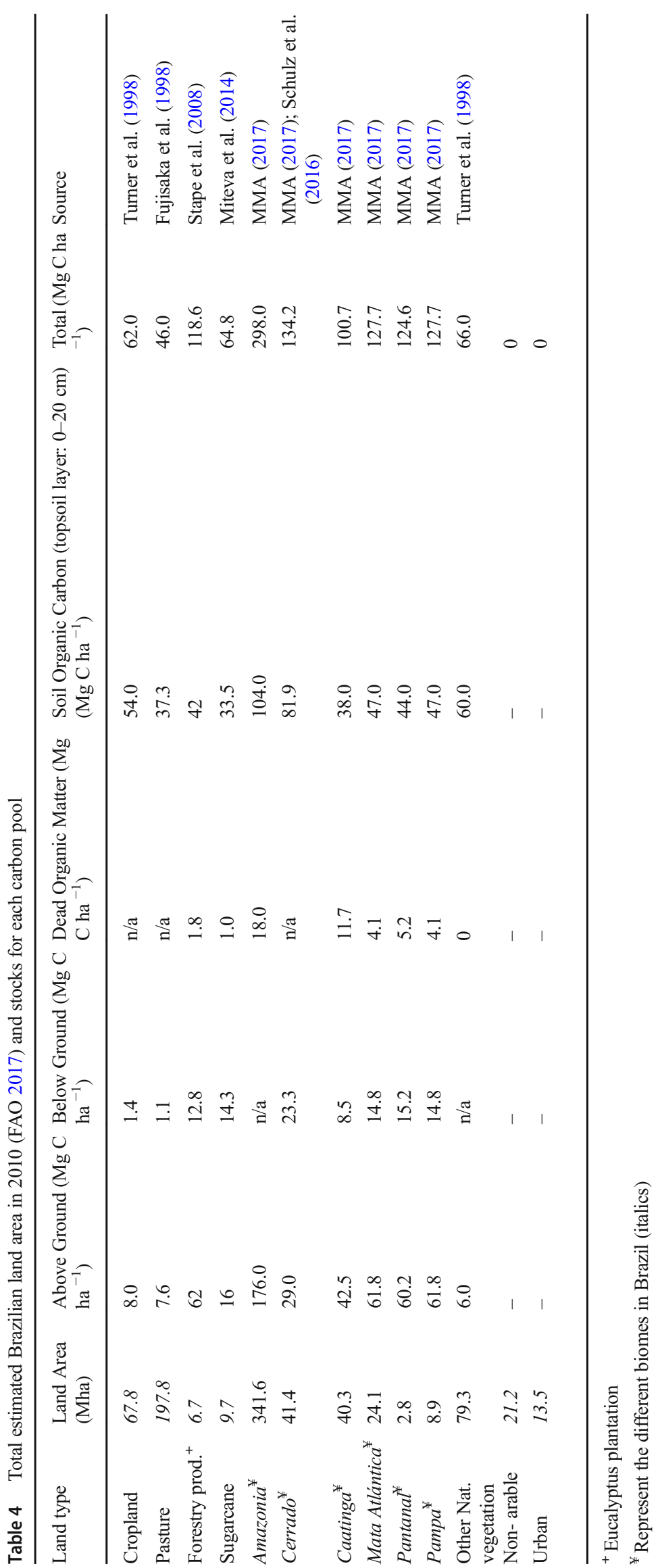




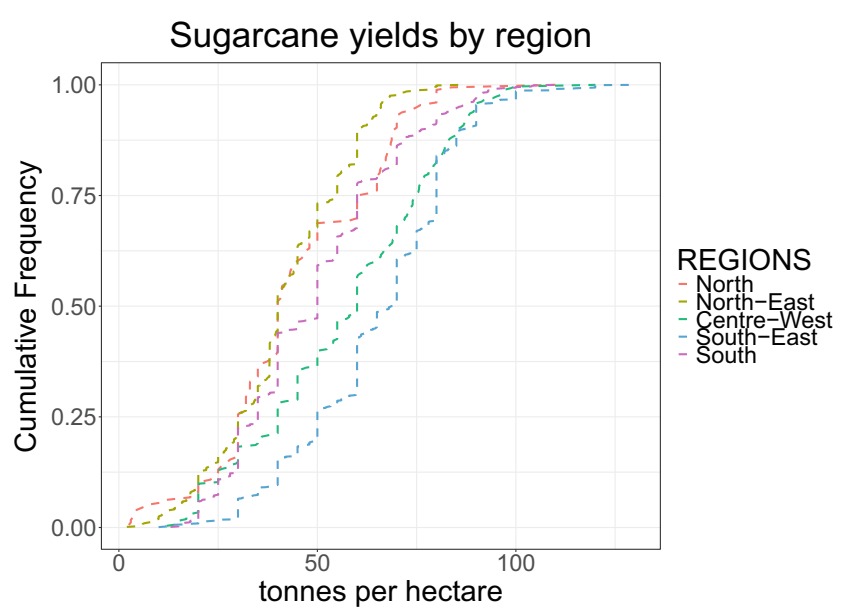

Fig. 4 Regional sugarcane yields distribution for 2015. Source: UNICA (UNICA 2018)

period. As shown in Fig. 12 in the Appendix, due to the regional food demand increase (Table 9), during the first 20 years of the simulation (2010-2030), the Centre-West region experiences a rapid increase in pasture land demand having medium-yielding technologies. As the region installs more modern technology and this becomes cheaper in further periods, it becomes available for producers to install highyielding technologies. Therefore, in later periods, as pasture and crops intensify at different rates in different regions, $\mathrm{C}$ losses suffer variations, mainly due to reduction in deforestation rates and the large amount of $\mathrm{C}$ flows to the atmosphere previously located in the SOC pools from pasture lands and biomass pools from croplands.

Nevertheless, the analysis would be incomplete, if the liberated land is not considered further.

\subsection{Implications of Reforestation or Sugarcane Expansion}

As mentioned in the scenario description, the aim is to study different uses of the liberated land at a regional level and its implication in $\mathrm{C}$ sequestration. Figure 8 shows the $\mathrm{C}$ sequestration rates if either a sugarcane expansion or a reforestation scenario is followed.

Based on the made assumptions, carbon storage and sequestration from reforestation has a larger $\mathrm{C}$ sink potential, especially in the Centre-West area. Tables 6 and 7 depict the

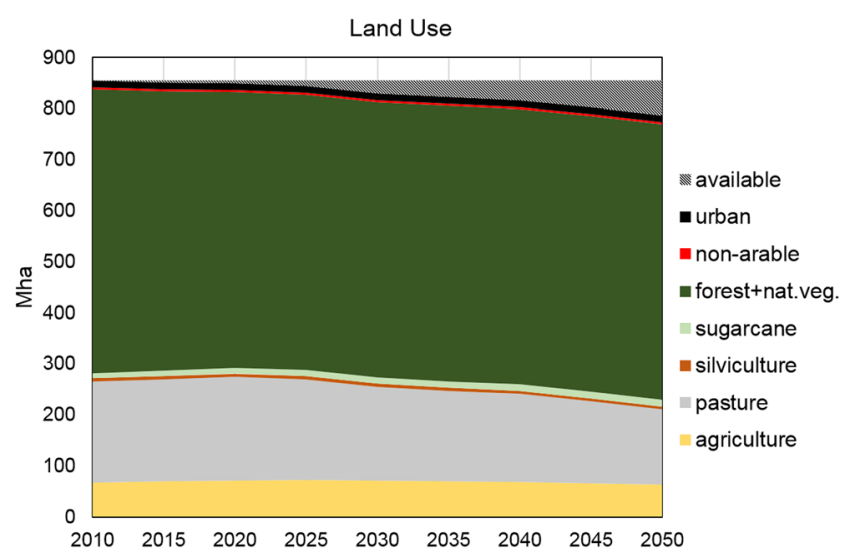

Fig. 5 Land use demand. Reference scenario

intra-period carbon stock for both scenarios for each of the regions. Compared to the reference scenario where available land has been left abandoned and the national carbon stock has been reduced by $4.4 \%$, from $135.9 \mathrm{PgC}$ to $129.9 \mathrm{PgC}$, if a sugarcane expansion scenario is followed, carbon stock losses would be minimal, only losing $1.2 \%$ compared to the baseline value (Table 6). In this scenario, the Centre-West region would still lose $11.3 \%$ of its baseline carbon stock. On the other hand, the South-East region would have $\mathrm{C}$ increase due to lack of deforestation and large agricultural dynamism. The main reason is the largest amount of sugarcane expansion in the liberated land due to faster intensification of pasture and the higher sugarcane productivity rates per unit area, which in turn results in more $\mathrm{C}$ sequestered in biomass pools per hectare.

For the reforestation scenario (Table 7), there is a potential to increase national carbon stock by $2.4 \%$, reaching $139.1 \mathrm{PgC}$ by 2050. The increase would mainly come from the Centre-West and South-East regions. On the other hand, the North-East region would decrease $\mathrm{C}$ stock due to lower amounts of liberated land combined with a biome (mainly Caatinga biome) with lower carbon content compared to the rest.

Figure 9 presents the $\mathrm{C}$ stock changes at each period for both scenarios. For the sugarcane expansion, net $\mathrm{C}$ changes are negative until 2030. This scenario is not able to offset $\mathrm{C}$ losses due to deforestation or pasture SOC losses. However, it achieves carbon sequestration rates between 2035 and 2050. Contrarily, the reforestation scenario can act as a sink already by 2025 . However, sequestration rates for the next 10 years after 2025 notably decrease due to high losses of SOC pools from pasture
Table 5 Sugarcane yields for base year and future projections. Source: UNICA (UNICA 2018)

\begin{tabular}{lllll}
\hline Regions & Percentile 2015 & ton ha ${ }^{-1} 2015$ & Percentile 2050 & ton ha ${ }^{-1} 2050$ \\
\hline North & 0.29 & 31.9 & 0.75 & 60.0 \\
North-East & 0.53 & 40.0 & 0.75 & 54.0 \\
Centre-West & 0.40 & 50.5 & 0.75 & 75.0 \\
South-East & 0.60 & 70.4 & 0.75 & 80.0 \\
South & 0.59 & 50.0 & 0.75 & 60.0 \\
\hline
\end{tabular}


Fig. 6 Carbon stock by region and by land. Reference scenario

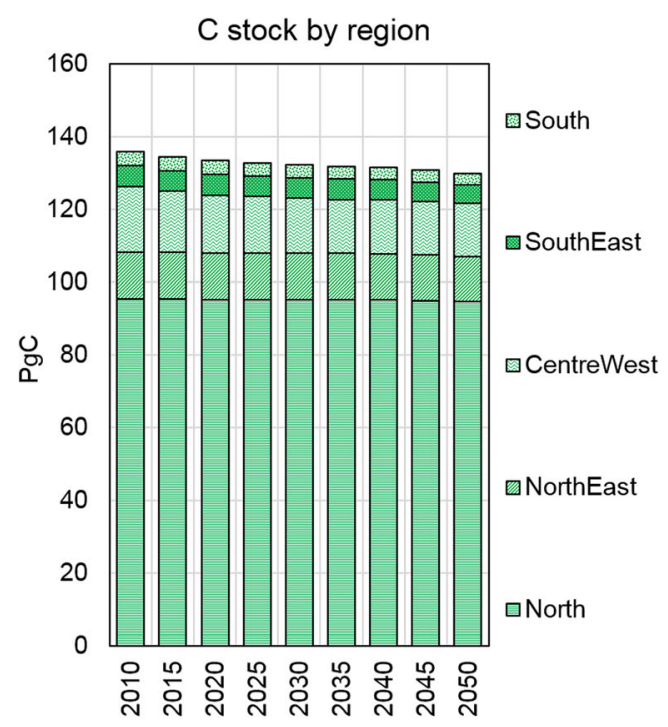

land liberation. In the following periods, sequestration rates are recovered, as the model accounts for reforestation in the cleared pasture lands from early years. This effect is due to the forest growth delay, as the model accounts for 30-year growing maturity rates, affecting instantaneous carbon uptake.

Finally, Fig. 10 compares the total carbon stock and the net changes for each scenario compared to the reference case. The reforestation scenario is capable to recover baseline $\mathrm{C}$ stocks by 2035 , while the sugarcane expansion scenario follows a constant small decrease over the simulation period.

\section{Discussions}

The potential contributions for carbon sequestration through either sugarcane expansion or reforestation in different regions of Brazil has been studied. Comparison of both scenarios as

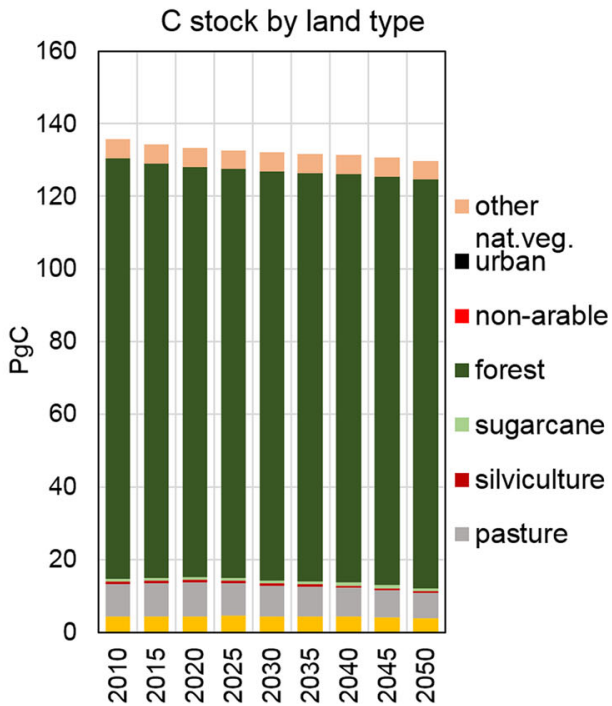

GHG abatement measures have revealed that large variations exist mainly based on assumed forestry recovery rates, sugarcane production, analysed region and biome, and agricultural commodity demand. Firstly, the model has shown that under a reference scenario and using the SSP2 socioeconomic pathway, due to large investments in modern agricultural technologies and practices, crops and pasture are expected to begin liberating important amounts of land by 2025, particularly in the Centre-West region where a very dynamic agricultural sector exists.

Results from sugarcane sequestration potential are in agreement with Evans et al. (2015), which calculated that sugarcane has a lower GHG offset potential than natural forest recovery, at least for the first 30 years, and even lower than intensive managed reforestation (65 years). However, higher sugarcane yields combined with large-scale production of biofuels could improve its GHG abatement potential. In this study, yield
Fig. 7 Carbon change by region and by land. Reference scenario
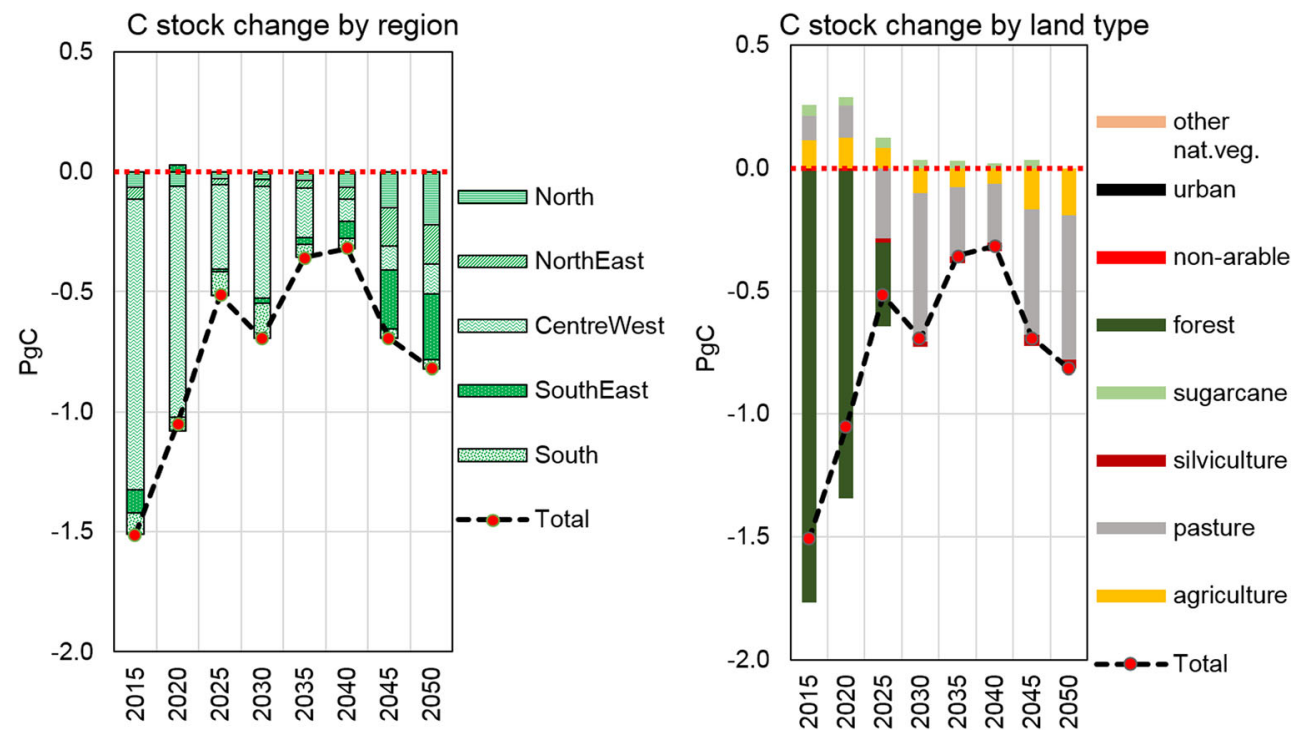
Fig. 8 Carbon stock for sugarcane expansion and reforestation scenarios

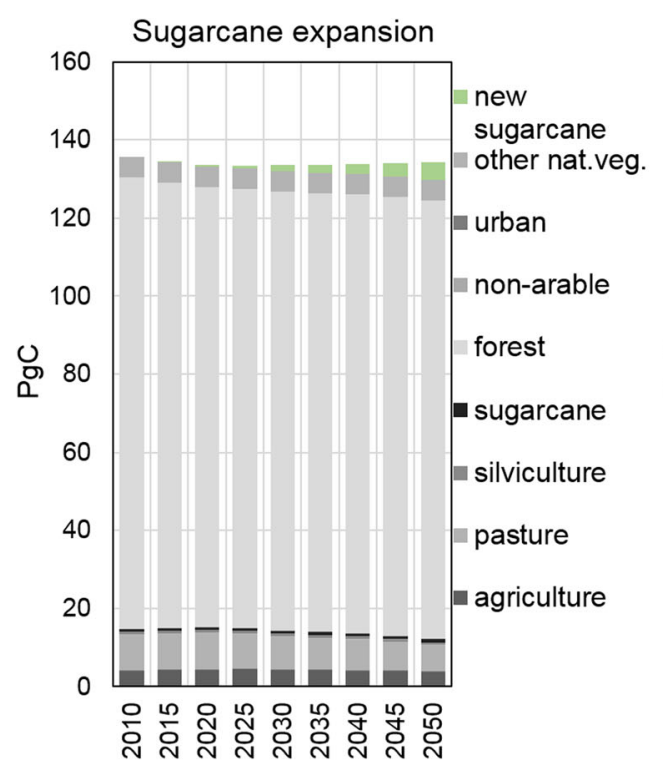

improvements have been considered for all regions (Table 5), constraining projections to base-year's high productivity levels (75th percentile) to avoid infeasible assumptions. Nevertheless, at the end of the analysed period, sugarcane expansion only was not able to offset $\mathrm{C}$ losses from land use management and land changes from other lands. Only the North and South-East regions were able to provide minimum $\mathrm{C}$ stock reductions. The North region due to the forest removal restrictions set in the model (especially in the Amazon region), while for the South-East, the higher sugarcane yields ( $\sim 80$ ton $\mathrm{ha}^{-1}$ ) provided larger amounts of $\mathrm{C}$ stocks per unit area in both biomass pools. However, the largest reduction potential from sugarcane is more evident in the energy system rather than in ecosystem services, by promoting large-scale utilization of bioethanol instead of gasoline in the transport sector.

When analysing the reforestation scenario, results indicate that carbon sequestration and storage potential from reforestation either in living biomass or in wood products could provide significant GHG abatement potential, especially in the North $(+1.5 \mathrm{PgC})$, South-East $(+1.0 \mathrm{PgC})$ and North-East $(+0.6 \mathrm{PgC})$ regions. The Centre-West lost $-0.3 \mathrm{PgC}$, mainly from an agricultural sector that is still in expansion and does not liberate agricultural land for the first 20 years, therefore deforestation still occurs. Added to that, when cleared land is available (mostly after 2035), the region has the lowest $\mathrm{C}$ succession rates from reforestation due to a lower carbon content forest by unit area such as the Cerrado forest.

Both scenarios presented could be regarded as hypothetical cases due to ecosystem or economic constraints. The later especially applies to sugarcane expansion, with a limited global market for sugarcane by-products such as sugar and ethanol. Additionally, the Brazilian government has limited the amount of area where sugarcane can be expanded (MAPA 2009). This is about $65 \mathrm{Mha}$, mainly from current agricultural and pasture land in the South-East and Centre-West regions. This agro-ecological zoning makes $92.5 \%$ of Brazilian territory unsuitable for sugarcane production. From the $65 \mathrm{Mha}$, 41.5 Mha are considered to have a medium potential level, 19.3 Mha with high potential level, and only 4.3 Mha have low potential level. The modelling outputs has estimated a total liberated land of about 68 Mha by 2050 , close to the limits suggested by the government. Overall, $76 \%$ of liberated

Table 6 Carbon stock per region for sugarcane expansion scenario

\begin{tabular}{|c|c|c|c|c|c|c|c|c|c|c|}
\hline \multirow[b]{2}{*}{ Regions } & \multicolumn{9}{|c|}{ Carbon stock $(\mathrm{PgC})$ - Sugarcane expansion scenario } & \multirow[b]{2}{*}{$\% \Delta \mathrm{C}$} \\
\hline & 2010 & 2015 & 2020 & 2025 & 2030 & 2035 & 2040 & 2045 & 2050 & \\
\hline North & 95.3 & 95.3 & 95.4 & 95.4 & 95.4 & 95.4 & 95.4 & 95.5 & 95.6 & $0.3 \%$ \\
\hline North-East & 12.8 & 12.8 & 12.8 & 12.8 & 12.9 & 12.9 & 12.9 & 12.9 & 13.0 & $1.1 \%$ \\
\hline Centre-West & 18.1 & 16.9 & 15.9 & 15.7 & 15.9 & 16.0 & 16.0 & 16.0 & 16.1 & $-11.3 \%$ \\
\hline South-East & 5.8 & 5.8 & 5.8 & 5.8 & 5.8 & 5.8 & 5.8 & 5.9 & 5.9 & $2.5 \%$ \\
\hline South & 3.9 & 3.8 & 3.7 & 3.8 & 3.8 & 3.8 & 3.8 & 3.8 & 3.8 & $-1.8 \%$ \\
\hline Total & 135.9 & 134.6 & 133.6 & 133.5 & 133.7 & 133.8 & 133.9 & 134.1 & 134.3 & $-1.2 \%$ \\
\hline
\end{tabular}


Table 7 Carbon stock per region for reforestation scenario

Carbon stock $(\mathrm{PgC})-$ Reforestation scenario

\begin{tabular}{lllllllllll}
\cline { 2 - 8 } Regions & 2010 & 2015 & 2020 & 2025 & 2030 & 2035 & 2040 & 2045 & 2050 & $\% \Delta \mathrm{C}$ \\
\hline North & 95.3 & 95.5 & 95.6 & 95.7 & 95.8 & 95.9 & 96.0 & 96.3 & 96.8 & $1.6 \%$ \\
North-East & 12.8 & 12.9 & 12.9 & 12.9 & 12.9 & 13.0 & 13.0 & 13.2 & 13.4 & $4.7 \%$ \\
Centre-West & 18.1 & 16.9 & 15.9 & 15.9 & 16.9 & 17.2 & 17.4 & 17.6 & 17.8 & $-1.4 \%$ \\
South-East & 5.8 & 5.8 & 5.8 & 5.8 & 5.9 & 5.9 & 6.0 & 6.4 & 6.7 & $16.8 \%$ \\
South & 3.9 & 3.8 & 3.7 & 3.9 & 4.1 & 4.2 & 4.2 & 4.3 & 4.3 & $11.0 \%$ \\
Total & 135.9 & 134.9 & 134.0 & 134.3 & 135.6 & 136.2 & 136.7 & 137.8 & 139.1 & $2.4 \%$ \\
\hline
\end{tabular}

land would come from former pasture land while the rest from previous agricultural and forestry land. However, if regional values are compared between modelling outputs and the sugarcane zoning programme (MAPA 2009), some differences can be found that eventually would reduce the sugarcane expansion potential in the model. For instance, the region with the highest amount of liberated land in the model has been the Centre-West region (23.0 Mha). This amount is below the total maximum suitable potential area provided by the government (30.3 Mha). A similar case occurs for the South-East region (13.5 Mha from the model against 22.7 Mha from the zoning programme). Therefore, for both regions (Centre-West and South-East) it has been assumed that the total liberated land calculated by the model can be used for sugarcane production. On the other hand, the model has calculated land liberation of 14.0 Mha for the North, 10.2 Mha for the North-East and 7.8 Mha for the South, well above the values provided by the government (North: 1.1 Mha, North-East: 5.2 Mha, South: 5.7 Mha). Therefore, the maximum suitable land for sugarcane expansion calculated by the model gets reduced from the original 68 Mha to $49 \mathrm{Mha}$; however, the model presented in this study is not capable to spatially explicitly locate if the liberated land is potentially suitable for sugarcane expansion, as located by the Brazilian authorities.

Figure 11 illustrates the maximum sugar and ethanol production potential from the sugarcane expansion scenario. Outputs show that by 2030 there is a maximum potential to produce around $1600 \mathrm{Mt}$ of sugarcane, and by 2050 this could increase to $5200 \mathrm{Mt}$. This value is five-fold compared to what is expected in the reference scenario of $1121 \mathrm{Mt}$. Also, high production in the North region might be infeasible due to the climatic characteristics of the Amazon, an ecosystem with lack of dry periods needed for sugarcane growth. However, recently new genetically modified (GM) sugarcane breeds have been tested that could provide producers in year-round humid regions with cost-effective sugarcane crops. Under current production levels and feedstock share dedicated to either sugar or ethanol, the hypothetical outputs represent the production of $324 \mathrm{Mt}$ of sugar and 214 billion litres of ethanol by 2050. To put this into perspective, in 2015 Brazil produced 34 Mt of sugar and 30 billion litres of ethanol. Globally, the overall production stands at about $180 \mathrm{Mt}$ for sugar and 100
Fig. 9 Carbon change by land stock for sugarcane expansion and reforestation scenarios
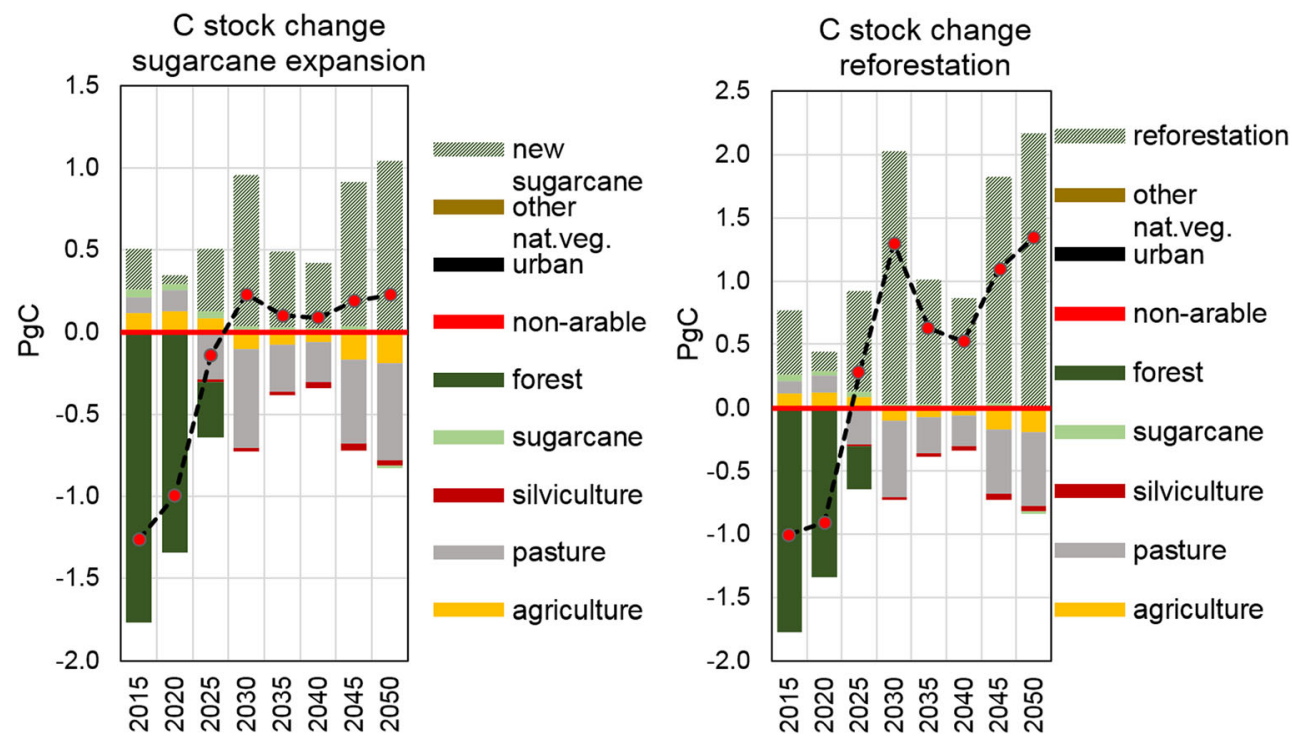
Fig. 10 Scenarios comparison of carbon stock and carbon change

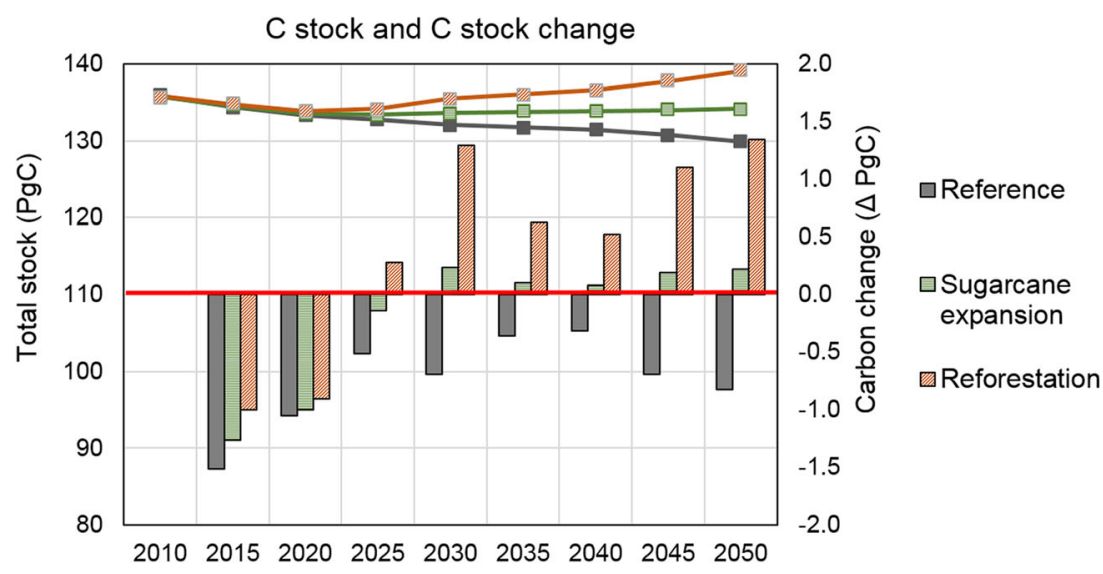

billion litres of ethanol. The aforementioned production (214 billion litres) has the capacity to reduce around $0.38 \mathrm{GtCO}_{2}$ $\mathrm{y}^{-1}$ from gasoline utilization in the transport sector. Moreover, if CCS is implemented in the ethanol production process, further reduction in GHG emissions could be achieved.

Recently, the country has presented the National Biofuels Policy (RenovaBio) (PLANALTO 2017), intending to reduce the transport sector emissions by $10.8 \%$ in 2028 , with significant contributions to Brazil's National Determined Contribution (NDC). The programme promotes a higher share of biofuel blending, focusing on incentivizing fuel distributors with an expected investment of around US\$ 20 billion (USDA 2018). If fully implemented, it is expected that annual production of ethanol will increase from current production of around 30 billion litres to between 43 and 54 billion litres by 2030 . As shown in Fig.11, the model has calculated a maximum production potential from sugarcane of 65 billion litres by 2030 , mainly produced in the South-East and Centre-West regions.

It is also expected that RenovaBio could boost the national corn ethanol industry aiming at reducing the country's imports of US corn ethanol. Nowadays, most of Brazil's corn ethanol production takes place in the Centre-West region, particularly in the state of Mato Grosso. Corn has developed as an important rotation crop in the region alongside soybean, experiencing a three-fold increase in its production during the last decade; however, accessibility to larger ethanol markets has restricted the local corn ethanol based industry to unlock its full potential. Currently, Brazil produces around 0.65 billion litres of corn ethanol (UNICA 2018), representing roughly $2 \%$ of the total national ethanol production. With the support of the RenovaBio programme, national projections estimate that corn ethanol could reach around 3.4 billion litres by 2030 , increasing the share of corn-based ethanol to about 6.2$7.9 \%$ of the national ethanol production.

Nevertheless, several uncertainties still exist for a sustainable increase in ethanol production in the country. The main ones refers to: i) the impacts on land use, food production and food prices, ii) the technological requirements to reach ethanol production targets, and iii) the interactions with other energy vectors at a national and global level, especially those regarding to the gasoline market share, where future oil prices could considerably affect blending targets as cheap oil could make anhydrous ethanol (blended with gasoline) a more economically attractive option than hydrous ethanol.
Fig. 11 Maximum sugarcane production by region and sugar/ ethanol production potential
Potential additional production of sugarcane and sugar/1G ethanol

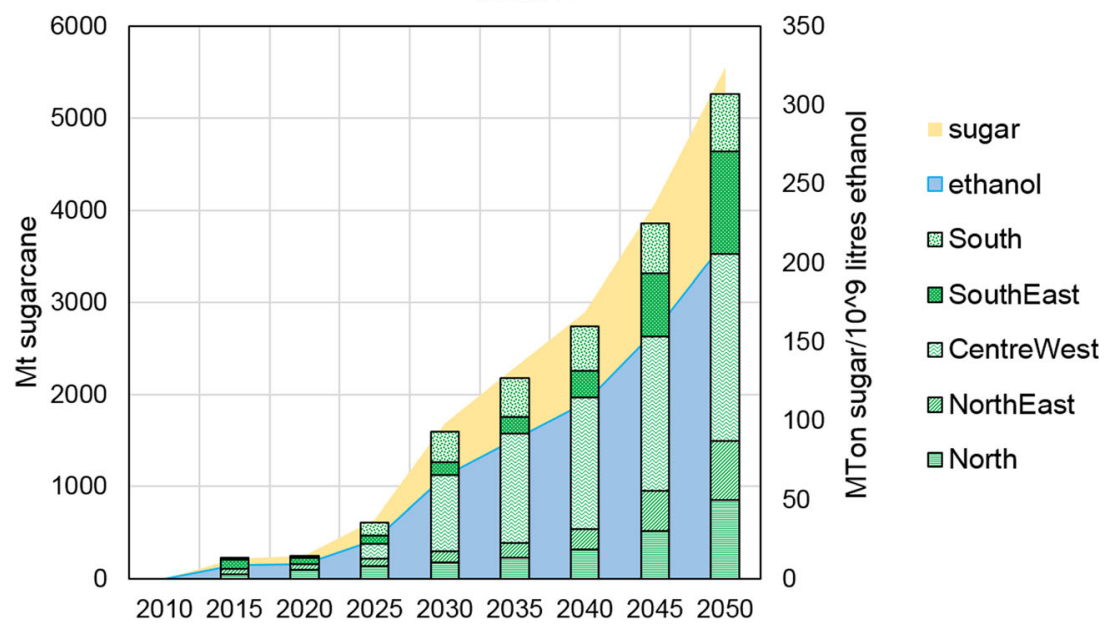




\section{Conclusion}

Due to increase in food demands, land competition and deforestation rates, the AFOLU sector would face some high environmental degradation, posing a risk in achieving global mitigation targets. In this paper we have expanded the energy system model MUSE allowing to investigate the carbon sequestration and storage potential from either bioenergy growth (in the form of sugarcane crops) or reforestation.

The model reference scenario has shown that Brazil has the potential to liberate up to $32.3 \mathrm{Mha}$ of agricultural land by 2035 (mainly from pasture intensification in the Centre-West region) and by 2050 this could reach $68.4 \mathrm{Mha}$. If this land is abandoned, the country's carbon stock could be reduced from 135.9 $\mathrm{PgC}$ in 2010 to $129.9 \mathrm{PgC}$ by 2050 . If a sugarcane expansion policy is followed, by mid-century the carbon stock could be recovered to $134.2 \mathrm{PgC}$, mainly due to the $\mathrm{C}$ sequestration in the above and below ground biomass pools. Although it would not be able to recover the baseline $\mathrm{C}$ stock value, further emission reductions in the transport sector can be achieved by substituting gasoline with either hydrous or anhydrous ethanol. On the other hand, a reforestation-only scenario projects that by 2035 the baseline year $C$ stock could be recovered and by 2050 it would be increased by $3.3 \mathrm{PgC}$, reaching positive annual sequestration rates of $+0.1 \mathrm{PgC} \mathrm{y}^{-1}$. $\mathrm{C}$ sequestration is mainly supported by the South-East and North regions. Brazil's tropical ecosystems, where tree forests have rapid growth rates, have the potential to become one of the largest GHG abatement regions in the world thanks due to its high $\mathrm{C}$ sequestration rates.

For any policy programme, both scenarios could be regarded as aggressive strategies that might not be sustainable. The uncontrolled expansion of sugarcane due to sugar and ethanol demand increase could lead to greater impacts on soil organic carbon (SOC) stocks as well as $\mathrm{NO}_{\mathrm{x}}$ emissions due to larger amounts of fertilizer used. Also, food prices could be affected due to lower available land for food cropping purposes. Yet, one of the main advantages of sugarcane expansion is the GHG emissions offset potential from sugarcane ethanol when it removes fossil-fuel based gasoline from the market (up to $0.38 \mathrm{GtCO}_{2} \mathrm{y}^{-1}$, globally). Nevertheless, appropriate bioenergy emissions account, especially those related to indirect land use remain to be investigated.

Carbon budgets and carbon policies often neglect the potential of forest and land use management. The obtained results suggest that reforestation should be regarded as an option for carbon mitigation as important as BECCS. But even though reforestation presented larger $\mathrm{C}$ sequestration potentials in this study, it also presents compromises between biodiversity, $\mathrm{C}$ sequestration and water usage. If well managed, reforestation could be an important measure to reduce and reverse biodiversity loss, otherwise it could also cause environmental degradation by altering precipitation, soil moisture and soil erosion. Although not analysed in this study, sugarcane-based ethanol production with CCS could hold an even greater potential to minimize energy emissions, increase energy security, and reduce dependency of fossil fuels at a local and global level. Nevertheless, for this to materialize, CCS technologies still need to become economically attractive either through technology cost reduction, commercialisation of captured $\mathrm{CO}_{2}$ (e.g. EOR) or government incentives.

GHG mitigation potential of either scenario should not be generalized as several limitations to this study should be considered when analysing the results. Uncertainty arises mainly from the model structure and assumptions made, especially in the carbon stocks and carbon changes due to land use management. Also, it is suggested that frameworks to estimate $\mathrm{C}$ pools and fluxes need to be standardized. This is fundamental if polices addressing forest $\mathrm{C}$ sequestration are going to be put in place. As MUSE is primarily an energy system model, for future work, a comparison of cost and technical implementation of industrial CCS and carbon capture from reforestation and land use management will be studied in more detail. Also, Nitrogen cycles dynamics during tropical reforestation and sugarcane growth will be quantified.

Acknowledgements The authors would like to acknowledge the Sustainable Gas Institute, Imperial College London and the Natural Environment Research Council (NERC) under the Newton Fund (NERC reference: NE/N018656/1) for funding this work.

Nomenclature $A B$, Above ground biomass; $B B$, Below ground biomass; $C$, Carbon; dom, dead organic matter; $G D P_{\text {cap }}$, Gross domestic product per capita; $l$, Carbon pool; $L U$, Land use

\section{Appendix}

Table 8 Soil carbon stock mean value response to different land sue changes. Source: Guo and Gifford (2002)

\begin{tabular}{lll}
\hline Land use Origin & Land use Destination & $\Delta$ SOC \\
\hline Forest & Pasture & $8 \%$ \\
Pasture & Secondary Forest & $-20 \%$ \\
Pasture & Silviculture & $-10 \%$ \\
Forest & Silviculture & $-13 \%$ \\
Crop & Silviculture & $18 \%$ \\
Forest & Crop & $-42 \%$ \\
Crop & Secondary Forest & $53 \%$ \\
Pasture & Crop & $-59 \%$ \\
Crop & Pasture & $19 \%$ \\
\hline
\end{tabular}


Table 9 Projection of regional crop and meat products demand in Brazil

\begin{tabular}{|c|c|c|c|c|c|c|c|c|}
\hline & \multicolumn{2}{|l|}{2010} & \multicolumn{2}{|l|}{2030} & \multicolumn{2}{|l|}{2050} & \multirow{2}{*}{$\begin{array}{l}\text { (2050/2010) } \\
\text { crops }\end{array}$} & \multirow{2}{*}{$\begin{array}{l}(2050 / 2010) \\
\text { meat }\end{array}$} \\
\hline & crops & meat & crops & meat & crops & meat & & \\
\hline Regions & $\mathrm{PJ} \mathrm{y}^{-1}$ & $\mathrm{PJ} \mathrm{y}^{-1}$ & $\mathrm{PJ} \mathrm{y}^{-1}$ & $\mathrm{PJ} \mathrm{y}^{-1}$ & $\mathrm{PJ} \mathrm{y}^{-1}$ & $\mathrm{PJ} \mathrm{y}^{-1}$ & $\%$ change & $\%$ change \\
\hline North & 61.0 & 18.4 & 76.7 & 23.9 & 82.1 & 26.8 & $34.6 \%$ & $45.8 \%$ \\
\hline North-East & 203.0 & 59.1 & 226.3 & 69.5 & 230.0 & 74.4 & $13.3 \%$ & $25.8 \%$ \\
\hline Centre-West & 54.6 & 17.7 & 69.9 & 23.5 & 74.6 & 26.3 & $36.5 \%$ & $48.2 \%$ \\
\hline South-East & 314.1 & 102.7 & 355.1 & 121.5 & 359.0 & 129.3 & $14.3 \%$ & $25.9 \%$ \\
\hline South & 106.7 & 34.2 & 121.0 & 40.8 & 121.9 & 43.3 & $14.3 \%$ & $26.6 \%$ \\
\hline Total & 739.3 & 232.1 & 849.1 & 279.2 & 867.5 & 300.0 & $17.3 \%$ & $29.3 \%$ \\
\hline
\end{tabular}

Fig. 12 Land use demand by regions. Reference scenario
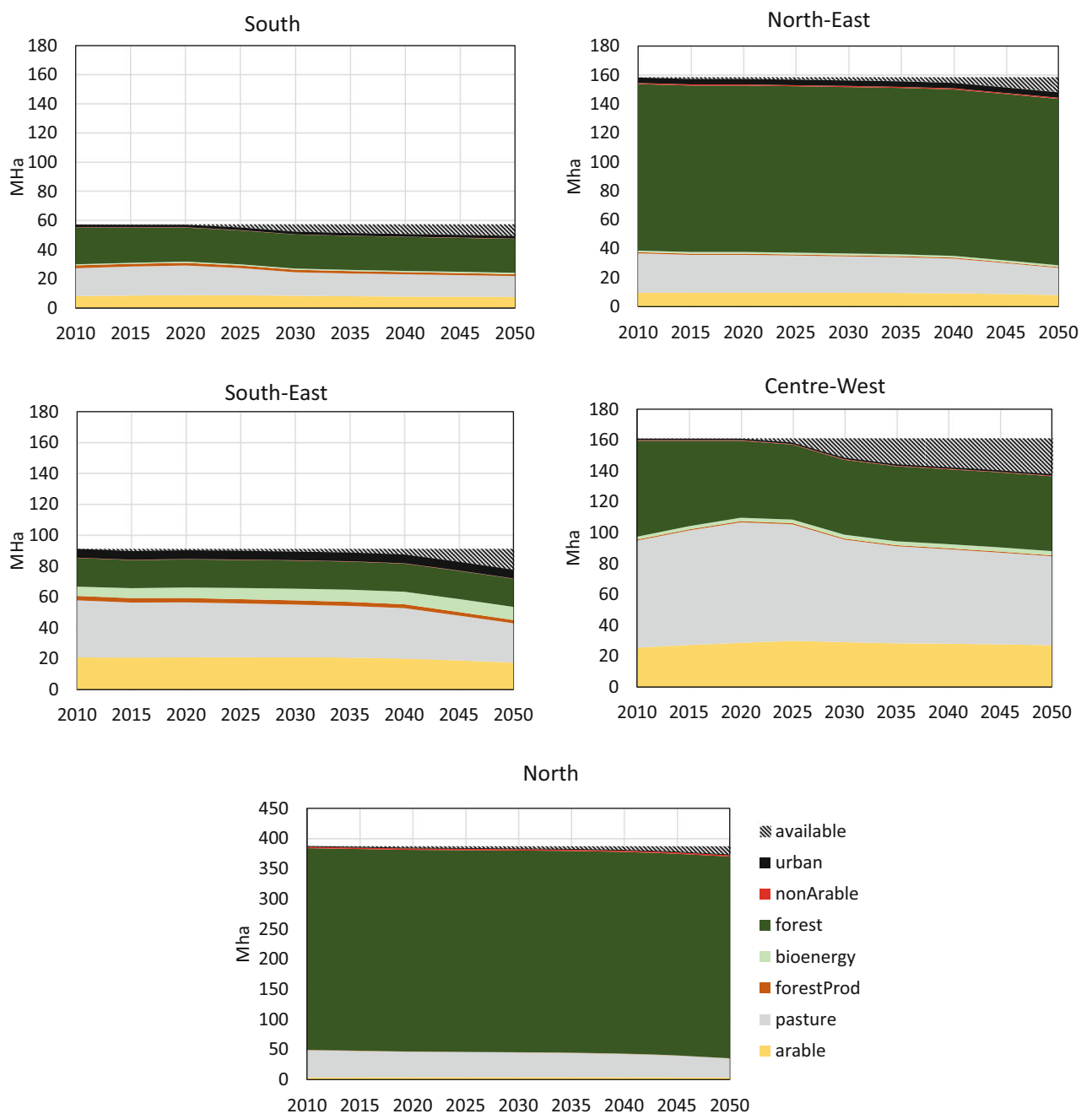
Open Access This article is distributed under the terms of the Creative Commons Attribution 4.0 International License (http:// creativecommons.org/licenses/by/4.0/), which permits unrestricted use, distribution, and reproduction in any medium, provided you give appropriate credit to the original author(s) and the source, provide a link to the Creative Commons license, and indicate if changes were made.

\section{References}

Albanito F, Beringer T, Corstanje R, Poulter B, Stephenson A, Zawadzka J, Smith P (2016) Carbon implications of converting cropland to bioenergy crops or forest for climate mitigation: a global assessment. GCB Bioenergy 8:81-95. https://doi.org/10.1111/gcbb.12242

Azar C et al (2010) The feasibility of low CO2 concentration targets and the role of bio-energy with carbon capture and storage (BECCS). Clim Chang 100:195-202. https://doi.org/10.1007/s10584-0109832-7

Crow DJG, Giarola S, Hawkes AD (2018) A dynamic model of global natural gas supply. Appl Energy 218:452-469. https://doi.org/10. 1016/j.apenergy.2018.02.182

De Oliveira Silva R, Barioni LG, Queiroz Pellegrino G, Moran D (2018) The role of agricultural intensification in Brazil's nationally determined contribution on emissions mitigation. Agric Syst 161:102112. https://doi.org/10.1016/j.agsy.2018.01.003

Deng YY, Koper M, Haigh M, Dornburg V (2015) Country-level assessment of long-term global bioenergy potential. Biomass Bioenergy 74:253-267. https://doi.org/10.1016/j.biombioe.2014.12.003

Dwivedi P, Khanna M, Sharma A, Susaeta A (2016) Efficacy of carbon and bioenergy markets in mitigating carbon emissions on reforested lands: a case study from southern United States. Forest Policy Econ 67:1-9. https://doi.org/10.1016/j.forpol.2016.03.002

EMBRAPA (2019) Biomas do Brasil - Empresa Brasileira de Pesquisa Agropecuária. Embrapa

EPE (2016) Plano Nacional de Energia - 2050. Ministerio de Minas e Energia. Rio de Janeiro, Brazil

Evans SG, Ramage BS, DiRocco TL, Potts MD (2015) Greenhouse gas mitigation on marginal land: a quantitative review of the relative benefits of Forest recovery versus biofuel production. Environ Sci Technol 49:2503-2511. https://doi.org/10.1021/es502374f

FAO (2017) FAOSTAT. Accessed 10 August 2017

Fearnside PM (2018) Brazil's Amazonian forest carbon: the key to southern Amazonia's significance for global climate. Reg Environ Chang 18:47-61. https://doi.org/10.1007/s10113-016-1007-2

Freitas FF et al (2019) The Brazilian market of distributed biogas generation: overview, technological development and case study. Renew Sust Energ Rev 101:146-157. https://doi.org/10.1016/j.rser.2018. 11.007

Fricko O et al (2017) The marker quantification of the shared socioeconomic pathway 2: a middle-of-the-road scenario for the 21st century. Glob Environ Chang 42:251-267. https://doi.org/10.1016/j. gloenvcha.2016.06.004

Fujisaka S, Castilla C, Escobar G, Rodrigues V, Veneklaas EJ, Thomas R, Fisher M (1998) The effects of forest conversion on annual crops and pastures:: estimates of carbon emissions and plant species loss in a Brazilian Amazon colony agriculture. Ecosyst Environ 69:17-26. https://doi.org/10.1016/S0167-8809(98)00091-7

García Kerdan I, Giarola S, Hawkes A (2019) A novel energy systems model to explore the role of land use and reforestation in achieving carbon mitigation targets: a Brazil case study journal of Cleaner Production. 232:796-821. https://doi.org/10.1016/j.jclepro.2019. 05.345
Guo LB, Gifford RM (2002) Soil carbon stocks and land use change: a meta analysis. Glob Chang Biol 8:345-360. https://doi.org/10.1046/ j.1354-1013.2002.00486.x

Haberl H, Beringer T, Bhattacharya SC, Erb K-H, Hoogwijk M (2010) The global technical potential of bio-energy in 2050 considering sustainability constraints. Curr Opin Environ Sustain 2:394-403. https://doi.org/10.1016/j.cosust.2010.10.007

Hasegawa T, Matsuoka Y (2010) Global methane and nitrous oxide emissions and reduction potentials in agriculture. J Integr Environ Sci 7: 245-256. https://doi.org/10.1080/19438151003621367

IBGE (2018) Natural resources and environmental studies - coverage and land use (Recursos Naturais e Estudos Ambientais - Cobertura e Uso da Terra). https://ww2.ibge.gov.br/home/geociencias/ recursosnaturais/usodaterra/default.shtm. Accessed 01/04/2018 2018

IPCC (2006) 2006 IPCC guidelines for National Greenhouse gas Inventories. UNEP

IPCC (2014) Climate change 2014: mitigation of climate change working group III contribution to the fifth assessment report of the intergovernmental panel on climate change, United Kingdom and New York

Krause A et al (2017) Global consequences of afforestation and bioenergy cultivation on ecosystem service indicators. Biogeosciences 14: 4829-4850. https://doi.org/10.5194/bg-14-4829-2017

Kraxner F, Nilsson S, Obersteiner M (2003) Negative emissions from BioEnergy use, carbon capture and sequestration (BECS) - the case of biomass production by sustainable forest management from seminatural temperate forests. Biomass Bioenergy 24:285-296. https:// doi.org/10.1016/S0961-9534(02)00172-1

MAPA (2009) Zoneamento Agroecológico da Cana-de-açúcar (ZAECana), Rio de Janeiro, RJ

Minx JC, Lamb WF, Callaghan MW, Bornmann L, Fuss S (2017) Fast growing research on negative emissions. Environ Res Lett 12: 035007

Miteva DA, Kennedy CM, Baumgarten L (2014) Carbon biophysical parameters applied to the Brazilian Cerrado

MMA (2017) Brazil's Forest reference emission level for reducing emissions from deforestation in the Cerrado biome for results-based payments for REDD+ under the United Nations framework convention on climate change vol working Group of Technical Experts on REDD+. Brasilia, df, Brazil

MME (2018) PROBIO - Project for the conservation and sustainable use of Brazilian biological diversity (Projeto de conservação e utilização sustentável da diversidade biológica Brasileira), Ministry of the Environment (Ministerio de Meio Ambiente ). Accessed 10/04/ 20182018

Moreira JR, Romeiro V, Fuss S, Kraxner F, Pacca SA (2016) BECCS potential in Brazil: achieving negative emissions in ethanol and electricity production based on sugar cane bagasse and other residues. Appl Energy 179:55-63. https://doi.org/10.1016/j.apenergy. 2016.06.044

Muratori M, Calvin K, Wise M, Kyle P, Edmonds J (2016) Global economic consequences of deploying bioenergy with carbon capture and storage (BECCS). Environ Res Lett 11:095004

Ni Y, Eskeland GS, Giske J, Hansen J-P (2016) The global potential for carbon capture and storage from forestry. Carbon Balance Manag 11:3. https://doi.org/10.1186/s13021-016-0044-y

Nijsen M, Smeets E, Stehfest E, Vuuren DP (2012) An evaluation of the global potential of bioenergy production on degraded lands. GCB Bioenergy 4:130-147. https://doi.org/10.1111/j.1757-1707.2011. 01121.x

Nobre CA, Sampaio G, Borma LS, Castilla-Rubio JC, Silva JS, Cardoso M (2016) Land-use and climate change risks in the Amazon and the need of a novel sustainable development paradigm. Proc Natl Acad Sci 113:10759. https://doi.org/10.1073/pnas.1605516113

PLANALTO (2017) Law No. 13576-Política Nacional de Biocombustíveis (RenovaBio). Available from: http://www. 
planalto.gov.br/ccivil_03/_ato2015-2018/2017/lei/L13576.htm [Accesed: August 06, 2019]

Plevin RJ, O'Hare M, Jones AD, Torn MS, Gibbs HK (2010) Greenhouse gas emissions from biofuels' indirect land use change are uncertain but may be much greater than previously estimated. Environ Sci Technol 44:8015-8021. https://doi.org/10.1021/es101946t

Quijas S et al (2019) Modelling carbon stock and carbon sequestration ecosystem services for policy design: a comprehensive approach using a dynamic vegetation model. Ecosystems and People 15:4260. https://doi.org/10.1080/26395908.2018.1542413

Scherer LA, Verburg PH, Schulp CJE (2018) Opportunities for sustainable intensification in European agriculture. Glob Environ Chang 48:43-55. https://doi.org/10.1016/j.gloenvcha.2017.11.009

Schulz K, Voigt K, Beusch C, Almeida-Cortez JS, Kowarik I, Walz A, Cierjacks A (2016) Grazing deteriorates the soil carbon stocks of Caatinga forest ecosystems in Brazil. For Ecol Manag 367:62-70. https://doi.org/10.1016/j.foreco.2016.02.011

Silver WL, Ostertag R, Lugo AE (2000) The potential for carbon sequestration through reforestation of abandoned tropical agricultural and pasture lands. Restor Ecol 8:394-407. https://doi.org/10.1046/j. 1526-100x.2000.80054.x

Slade R, Saunders R, Gross R, Bauen A (2011) Energy from biomass: the size of the global resource. Imperial College Centre for Energy Policy and Technology and UK Energy Research Centre, London

Smeets EMW, Faaij APC, Lewandowski IM, Turkenburg WC (2007) A bottom-up assessment and review of global bio-energy potentials to 2050. Prog Energy Combust Sci 33:56-106. https://doi.org/10. 1016/j.pecs.2006.08.001

Smith P et al (2013) How much land-based greenhouse gas mitigation can be achieved without compromising food security and environmental goals? Glob Chang Biol 19:2285-2302. https://doi.org/10.1111/gcb. 12160

Stape JL, Binkley D, Ryan MG (2008) Production and carbon allocation in a clonal Eucalyptus plantation with water and nutrient manipulations. For Ecol Manag 255:920-930. https://doi.org/10.1016/j. foreco.2007.09.085

Turner D, Winjum JK, Kolchugina TP, Vinson TS, Schroeder PE, Phillips DL, Cairns M (1998) Estimating the terrestrial carbon pools of the former Soviet Union, conterminous U.S., and Brazil vol 9. https:// doi.org/10.3354/cr009183

UN (2015) Framework convention on climate change: adoption of the Paris agreement. United Nations, 21st conference of the parties, Paris

UNICA (2018) Unicadata - Brazilian sugarcane industry association. Accessed 03/03/2018 2018

USDA (2018) Brazil Biofuels Annual 2018. USDA Foreign Agricultural Service. Global Agricultural Information Network (GAIN)

Yue Q, Xu X, Hillier J, Cheng K, Pan G (2017) Mitigating greenhouse gas emissions in agriculture: from farm production to food consumption. J Clean Prod 149:1011-1019. https://doi.org/10.1016/j. jclepro.2017.02.172

Publisher's Note Springer Nature remains neutral with regard to jurisdictional claims in published maps and institutional affiliations. 